\title{
Correlation study and histopathological description of intestinal alterations in dogs infected with Leishmania infantum
}

\author{
Estudo de correlação e descrição histopatológica das lesôes intestinais \\ de cães infectados com Leishmania infantum
}
Diogo Tiago Silva ${ }^{1}$; Maria Francisca Neves ${ }^{1}$; Nina Mari Gual Pimenta de Queiroz ${ }^{1}$; Julio Cesar Pereira Spada ${ }^{1}$; Maria Luana Alves'; Marina Flóro e Silva'; Willian Marinho Dourado Coelho²; Alan Rodrigo Panosso ${ }^{3}$; Antonio Carlos Faconti Noronha Junior ${ }^{4}$; Wilma Aparecida Starke-Buzetti ${ }^{1 *}$

\author{
${ }^{1}$ Departamento de Biologia e Zootecnia, Universidade Estadual Paulista - UNESP, Campus de Ilha Solteira, Ilha Solteira, SP, Brasil \\ ${ }^{2}$ Fundação Educacional de Andradina - FEA, Andradina, SP, Brasil \\ ${ }^{3}$ Departamento de Matemática, Universidade Estadual Paulista - UNESP, Campus de Ilha Solteira, Ilha Solteira, SP, Brasil \\ ${ }^{4}$ Centro de Controle de Zoonoses, Ilha Solteira, SP, Brasil
}

Received August 10, 2015

Accepted December 9, 2015

\begin{abstract}
The aim of this work was a correlation study and histopathological description of alterations associated with the presence of Leishmania infantum amastigote in the intestinal wall of dogs infected with canine visceral leishmaniasis (CVL). Three groups were used: G1 $(\mathrm{n}=8)$, comprising naturally infected dogs with CVL with amastigotes of L. infantum in the small and large intestines; G2 ( $=9$ ), infected dogs with CVL, without intestinal amastigotes; and G3 ( $=3$ ), uninfected dogs. Histochemistry and immunohistochemistry methods were used for histopathology and amastigotes identification. 47.1\% (8/17) of dogs from G1 group had amastigotes in the mucosa, submucosa and muscle layers of the small and large intestines and it was observed a prominent inflammatory reaction characterized by chronic infiltration of mononuclear cells: macrophages, lymphocytes and plasma cells. Comparison between the groups showed only a significant difference in relation to mucosal microscopic structural alterations in dogs from G1 in relation to G2 and G3. Parasite burden showed significant correlations with the microscopic alterations and clinical status of dogs in G1. By the conclusion, the inflammatory reactions caused by the parasites in the intestines might have contributed towards alterations in digestive processes, worsening the dogs' clinical status of CVL.
\end{abstract}

Keywords: Dog, histology, immunohistochemistry, intestine, leishmaniasis, amastigotes.

\section{Resumo}

O objetivo foi realizar um estudo de correlação e descrição histopatológica das lesôes associadas à presença de amastigotas de Leishmania infantum na parede intestinal de cães infectados com leishmaniose visceral canina (LVC). Os cães foram subdivididos em três grupos: G1 $(n=8)$ cães naturalmente infectados com LVC e com amastigotas de L. infantum no intestino; G2 $(\mathrm{n}=9)$ com LVC, mas sem o parasitismo intestinal; e $\mathrm{G} 3(\mathrm{n}=3)$ cães não infectados. Métodos histoquímicos e imunoistoquímicos foram utilizados para a histopatologia e a identificação das amastigotas, respectivamente. $47,1 \%$ (8/17) dos cães infectados (grupo G1) apresentavam formas amastigotas na mucosa, submucosa e camada muscular do intestino delgado e grosso, destacando-se uma reação inflamatória caracterizada por infiltrado crônico de células mononucleares; macrófagos, linfócitos e plasmócitos. Observou-se uma diferença significativa somente com relação às alterações estruturais microscópicas intestinais nos cães do G1 quando comparadas com G2 e G3. A intensidade parasitária intestinal teve correlação significativa com as alteraçóes microscópicas e os sinais clínicos dos cães do G1. Concluiu-se que as amastigotas de L. infantum por causarem reaçóes inflamatórias na parede intestinal dos cães podem ter contribuído para as alteraçóes dos processos digestórios, agravando ainda mais o quadro clínico dos animais.

Palavras-chave: Cão, histologia, imunoistoquímica, intestino, leishmaniose, amastigotas.

*Corresponding author: Wilma Aparecida Starke Buzetti. Departamento de

Biologia e Zootecnia, Faculdade de Engenharia, Universidade Estadual Paulista

- UNESP, Campus de Ilha Solteira, Av. Brasil, 56, CEP 15385-000,

Ilha Solteira, SP, Brasil. e-mail: starke@bio.feis.unesp.br 


\section{Introduction}

Canine visceral leishmaniasis (CVL) is a disease caused by protozoa of the genus Leishmania (ROSS, 1903). The species Leishmania infantum (syn. L. chagasi) is the causative agent of visceral leishmaniasis in the New World, with endemic regions extending from the southern USA to northern Argentina, including Brazil (KUHLS et al., 2011).

The main route for parasite transmission to human and animals is through the bite of the sand flies species Lutzomyia (L.) longipalpis (Diptera: Psychodidae: Phlebotominae) (PORROZZI et al., 2006). Because of the close association between dogs and humans, dogs play an important role in transmitting the disease to humans. The canine skin is the body system that most commonly presents signs of CVL and the presence of Leishmania parasites in dog skin emphasizes the importance of the role played by domesticated canids in the life cycle of $L$. infantum (QUEIROZ et al., 2010). Once inoculated into the host's skin, the parasite multiplies inside the cytoplasm of macrophages, thereby causing alterations especially to the liver, lymph nodes, spleen, bone marrow and gastrointestinal tracts.

The infection compromises not only the liver, spleen, lymph nodes and bone marrow, but also other organs such as the gastrointestinal, central nervous, genital and urinary systems (BLAVIER et al., 2001; ALVAR et al., 2004; SOLANO GALLEGO et al., 2001). Classic canine leishmaniasis appears clinically as a chronic wasting disease, with anemia, cutaneous lesions, generalized lymphadenopathy, glomerulonephritis, epistaxis, chronic colitis, hemorrhagic diarrhea, arthritis, ophthalmic lesions, keratoconjunctivitis or uveitis (CHAPMAN \& HANSON, 1984; CHANG et al., 1985; FERRER et al., 1991; CIARAMELLA et al., 1997; BLAVIER et al., 2001; TAFURI et al., 2001).

An inflammatory reaction in the gastrointestinal tract associated with the presence of intramacrophagic Leishmania amastigotes has been reported in experimentally infected dogs (CHIAPELLA, 1986; KEENAN et al., 1984a, b) and in naturally infected dogs (FERRER et al., 1991; PINTO et al., 2011; TOPLU \& AYDOGAN, 2011). In experimental studies using hamsters as models for this infection, González et al. (1986) described the pathological alterations occurred in the intestinal lamina propria and submucosa of the colon, caused by the parasites associated with inflammatory cell infiltration of lymphocytes, plasma cells and macrophages. Although uncommon, occurrences of erosive and ulcerative colitis and hemorrhagic diarrhea have sometimes been described in dogs in association with severe clinical signs of this disease (GONZÁLEZ et al., 1990; FERRER et al., 1991). However, the prevalence of Leishmania parasitism detected in the colonic mucosa through colonoscopy, but without overt colitis, was surprisingly high in dogs with symptomatic leishmaniasis (ADAMAMA-MORAITOU et al., 2007).

More recently, Silva et al. (2002) and Pinto et al. (2011) investigated symptomatic dogs that were naturally infected with L. infantum and observed high parasite burden throughout the intestinal mucosa (predominantly in the colon) without marked pathological alterations, which suggested that Leishmania might be a cause of intestinal immunological tolerance.
Thus, the purpose of this research was a correlation study and histopathological description of intestinal alterations associated with the presence of Leishmania infantum amastigotes in intestines of dogs with canine visceral leishmaniasis.

\section{Materials and Methods}

\section{Animals and location}

Dogs for the present study were from Ilha Solteira $\left(51^{\circ} 06^{\prime} 35^{\prime \prime} \mathrm{O}\right.$;

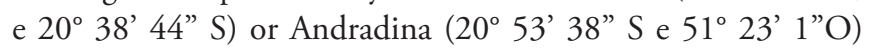
municipalities, which are endemic areas for CVL, located in the northwestern region of the state of São Paulo, Brazil.

The dogs were divided into three experimental groups: group 1 $(\mathrm{G} 1, \mathrm{n}=8)$, dogs with CVL and with amastigotes of $L$. infantum in the intestine; group $2(\mathrm{G} 2, \mathrm{n}=9)$, dogs with CVL, but without intestinal amastigotes; and group $3(\mathrm{G} 3, \mathrm{n}=3)$, dogs uninfected for CVL (control group).

This study was approved by the Ethics Committee for Animal Use (CEUA) of Sáo Paulo State University, Ilha Solteira Campus, (FEIS-UNESP), Department of Biology and Animal Science, under protocol no. 06/2014-CEUA.

\section{CVL diagnosis}

\section{CVL infected dogs (G1 and G2 group)}

During the epidemiological survey, dogs were diagnosed for CVL in the Zoonosis Control Center (ZCC) of Ilha Solteira, SP, by the following methods: (a) direct parasitological examination of popliteal or pre-scapular lymph node aspirate stained with Panotico staining kit (Laborclin ${ }^{\circledR}$ ), (b) immunochromatographic test $\mathrm{DPP}^{\circledR}$ (Dual Parth Platform) as a screening test and (c) an indirect ELISA test (Biomanguinhos kit) for confirmation.

After the confirmation of CVL, 17 symptomatic infected dogs were spontaneously left in the ZCC by their owners for euthanasia and they were donated by the ZCC for this work.

Then, the serological tests of these animals were repeated in our laboratory using an indirect ELISA test and IFAT (indirect fluorescent antibody test) according to Oliveira et al. (2008), and molecular analysis of the blood were also performed by PCR (polymerase chain reaction) according to standard protocol used by Assis et al. (2010). All these tests were again positive for CVL.

In addition to the laboratorial exams, the clinical status of the dogs were also evaluated before and after the euthanasia. For that, each dog was examined according to the description of Feitosa et al. (2000) for CVL. The macroscopic condition of the organs, such as spleen, liver, kidney, lymph nodes and the intestines were also observed and recorded during the necropsy.

These infected dogs were symptomatic for CVL due several clinical and anatomopathological signs of the disease, including onychogryphosis $(65 \%)$, skin lesions $(65 \%)$, slender $(60 \%)$, hypertrophic lymph nodes (55\%), alopecia (45\%), splenomegaly (45\%), hepatomegaly (25\%), corneal opacity (25\%) and diarrhea $(10 \%)$. 


\section{CVL uninfected dogs (G3)}

The uninfected dogs died because of traffic accidents, but before the death, the animals were taken care in a veterinary clinic where feces, urine, lymph node, bone marrow and blood samples were collected for clinical, parasitological, biochemical and serological exams. However, the results of these exams turned out negative and the dogs had no any clinical signs of leishmaniasis.

Regarding about the biochemical exams, hepatic and renal function of these control dogs (G3) were assessed through measurements of alanine aminotransferase (ALT2S kit, ref 04657373); aspartate aminotransferase (ASTL kit, ref 04,657,543); urea (UREAL kit, ref 04657616) and creatinine (CREJ2 kit, ref 05401755) using the Cobas c111 system ${ }^{\circledR}$ Analyser (Roche Instrument Center - SWITZERLAND, number 10276, 4528778001 cod.). The results were compared with reference values for dogs.

\section{Euthanasia and necropsy procedures for tissue sample collection}

The dogs with CVL were submitted to euthanasia in accordance with Decree no. 51,838 of Brazilian Federal law, published on March 14, 1963, which recommends that dogs infected with CVL should be euthanized. The procedure no.1000/2012 from the Brazilian Federal Council of Veterinary Medicine was followed for the euthanasia. The infected dogs were euthanized and necropsied at the Zoonosis Control Center of Ilha Solteira, SP.

After euthanasia, the abdominal cavities of dogs were opened for examination and organs and tissues were removed. The small intestine (duodenum, jejunum and ileum) was separated from the large intestine (ascending colon) and 0.5 to $1 \mathrm{~cm}$ fragments were collected for histopathological and immunohistochemical procedures.

In addition, for CVL confirmation, imprinting of the organs (spleen, liver and spleen) were also done for a direct microscopic parasite examination in appropriate Giemsa staining. Amastigotes of the parasites were identified in the tissues of these infected dogs.

The necropsy and tissue collection of the negative control dogs were accomplished with similar procedures as described above.

\section{HE stained histopathology and immunohistochemistry}

The intestinal tissue samples collected from G1, G2 and G3 groups of dogs were fixed in $0.01 \mathrm{M}$ phosphate-buffered $10 \%$ formalin solution for routine histological and immunohistochemical procedures.

The intestinal tissues were fixed and then embedded in paraffin. Histological sections of $5 \mu \mathrm{m}$ thickness were cut and stained with hematoxylin and eosin (HE) for histopathological examination.

The presence of amastigotes and the structural alterations were evaluated in the mucosa, submucosa and smooth muscle layers of the small intestine (duodenum, jejunum and ileum) and large intestine (colon). The tissues were examined under an optical microscope (three sections from each intestinal tissue sample).

Tissue samples from the liver, spleen and popliteal lymph nodes were also collected, processed and stained by HE. The L. infantum amastigotes identified in these organs demonstrated the visceral leishmaniasis.

For immunohistochemical analysis (TAFURI et al., 2004; QUEIROZ et al., 2011), deparaffinized slides were hydrated and incubated in hydrogen peroxide (Fluka Chemie AG, CH-9470 Buchs, Switzerland) to block endogenous peroxidase activity. This was followed by incubation with normal goat serum (1:50 dilution) to block nonspecific immunoglobulin absorption in the tissue. Hyperimmune serum from a dog that was naturally infected with L. infantum (ELISA and IFAT; titer $=1: 2560$ ) was used as the primary antibody. The secondary antibody was a biotinylated goat anti-rabbit reagent (BA-1000, Vector Laboratories, Inc., Burlingame, CA, USA) (canine cross-immune reaction). After appropriate washes, the tissues were incubated with a solution of avidin-biotin-complex peroxidase (Vectastain ABC Kit PK 6200; Vector Laboratories Inc., Burlingame, CA, USA), followed by incubation with the peroxidase substrate (Nova RED ${ }^{\mathrm{TM}}$ substrate Kit SK-4800; Vector Laboratories Inc., Burlingame, CA, USA). Finally, the slides were dehydrated, cleared, counter-stained with Mayer's hematoxylin and mounted with coverslips.

The tissue samples treated as described above were considered positive when extra or intramacrophagic amastigote forms were specifically immunostained with red/brown color in at least one tissue section, after examination of three tissue sections per intestinal segment (duodenum, jejunum, ileum and colon) of each dog under an optical microscope (objective lenses of $40 \times$ or $100 \times$ ). Positively immunostained amastigote profiles were identified under the microscope and these cells were counted in the lamina propria of the villi and the crypts, submucosa and smooth muscle layer (tunica muscularis externa) of the intestinal wall. Immunostained positive macrophages in the mucosal lamina propria were counted separately for the villus and crypt regions. Individual values for crypts and villi were combined to create the number of immunostained positive cells per villus-crypt unit (VCU), in accordance with the method of Miller \& Jarrett (1971). Counts of amastigotes in the submucosa (SM), and in the circular (CM) and longitudinal (LM) smooth muscle layers, were based on counts per layer in an area equal to the width of the VCU located immediately between the submucosa and the lumen, under a microscope in a $40 \times$ lens field, as described by Starke \& Oaks (2001). Ten VCU from three separate tissue sections were used to assess positive immunostained macrophage numbers from each region per $\mathrm{dog}$.

According to the presence or absence of amastigotes in intestinal layers, the CVL infected dogs were classified as G1 or G2, respectively.

For cell counting, the observer was kept unaware of the parasite status of each intestinal region, to avoid operator bias.

\section{Scores for variables}

The variables analyzed were the L. infantum parasite burden in the intestines, clinical signs and body scores of the dogs, and macro and microscopic structural alterations of the intestinal wall. Thus, for comparison and correlation analysis, these variables received 
scores ranging from 1 to 4 , which the score 1 was considered the lowest and 4 the highest level for each variable analyzed.

The following variables were analyzed using the parameters listed below:

Parasite burden (PB): The parasite burden was determined based on the numbers of macrophages infected with amastigotes identified according to the immunohistochemical method, through observations on at least 100 microscopic visual fields (objective of $40 \times$ ) in the duodenum, jejunum, ileum and colon. The scores for parasite burden were classified as follows. Negative: uninfected dogs with tissue sections without any amastigote. Score $1(+)$ : low parasite burden with 1-50 infected macrophages. Score $2(++)$ : 51-100 infected macrophages with moderate parasite burden; Score $3(+++)$ : 101-200 infected macrophages with high parasite burden. Score $4(++++)$ : more than 200 infected macrophages with very high parasite burden.

Clinical signs (CS): Dogs without any clinical sign (Score 1); dogs with up to three typical clinical signs of CVL, as example: onychogryphosis, cutaneous alterations, hypertrophic lymph nodes. (Score 2); dogs with four to six clinical signs of CVL, as example: cutaneous alterations, weight loss, onychogryphosis, ocular lesions, lesions at the ear tips, hypertrophic lymph nodes, splenomegaly, pallid mucosa, etc. (Score 3); dogs with more than six clinical signs, as exemplified above, including cachexia, hepatosplenomegaly, renal insufficiency, etc. (Score 4).

Body score (BS): dogs with normal body mass (score 1); slightly thin (score 2); very slim with the vertebrae visible under the skin (score 3); cachexia, apathy, slowness of movement (score 4).

Macroscopic structural alteration (MaA): Score 1: normal mucosa, without apparent alteration. Score 2: hemorrhage at scattered points in the small and large intestines. Score 3: presence of petechial hemorrhages along the intestine and increased presence of mucus. Score 4: intense lesion in the mucosa, liquid intestinal contents, diarrhea and sometimes bloody stools, and stools with large amount of mucus.

Mucosal microscopic structural alteration (MiA): mucosal microscopic alterations were examined using HE staining, as follows. Score 1: normal mucosa, without any cellular and morphological alteration. Score 2: cellular alteration, but with normal epithelium, mild edema and mucosal congestion Score 3: with little disruption of the epithelium, particularly on the tips of villi, moderate edema, congestion or hemorrhage and thickening of the lamina propria of the villi and crypts, along with hypertrophic Peyer's patches. Score 4: extensive destruction of villus epithelial layer, evident edema, congestion and hemorrhage, flattening of villi (atrophy), thickening of the mucosa and submucosa, presence of granulomas and hypertrophic Peyer's patches.

\section{Intestinal parasitological exams}

The intestinal parasitological evaluation included fecal analysis using the following techniques (a) method of Willis (1921); (b) method of Gordon \& Whitlock (1939) using McMaster camera; and (c) method of concentration by spontaneous sedimentation (HOFFMAN et al., 1934). In addition, the fecal sample cultures with $2 \%$ potassium dichromate at room temperature for 6-10 days were used for coccidian oocyst sporulation and identification.

The intestinal contents were also analyzed under a stereomicroscope.

Only negative dogs for co-infection with other intestinal parasitic agents were included in this work.

\section{Statistical analysis}

The scores of the variables analyzed in this work were used for comparison analysis and correlation using the $\mathrm{R}$ software, version 3.1.1 (R CORE TEAM, 2015). The statistical test used to comparing variables in the three groups of dogs was Kruskal-Wallis and for multiple comparisons between the medians of each group it was used the Bonferroni test. Correlations between the different variables of the dogs in Group 1 (G1) were made using the Spearman correlation test. Both tests were based on $95 \%$ confidence intervals, such that $\mathrm{p}$ values $\leq 0.05$ were considered statistically significant.

\section{Results}

\section{Parasite burden}

In this study, $85 \%(17 / 20)$ of the dogs were serologically and parasitologically positive and symptomatic for CVL.

L. infantum amastigotes were seen in the intestinal wall of $47.1 \%(8 / 17)$ symptomatic dogs, including the lamina propria of the mucosa (VCU), submucosa (SM) and smooth muscle $(\mathrm{Mu})$. Abundant amastigotes were detected inside hypertrophic macrophages in the mucosa of the small intestine in the majority of the cases, particularly in the tips of the villi. Immunostained macrophages containing $L$. infantum amastigotes were semi-quantified in tissue sections in different intestinal wall layers (Table 1 ). The mucosa, particularly of dogs numbers 1, 2 and 4, was the most intensely infected site, with parasite loads reaching up to ++++ (score 4$)$, in the duodenum, jejunum, ileum or colon (Table 1). The submucosa of all intestinal segments was infected with moderate numbers of parasites (score $2 ;++$ ), while the circular (CM) or longitudinal (LM) smooth muscle layers were less infected (score $1 ;+$ ). Most of the dogs were negative in the smooth muscle, particularly around the myenteric nervous plexus, only seen in the small intestines.

According to Table 1, 50\% (4/8) of the animals had amastigotes in the duodenum and jejunum, in at least one region of the intestinal wall (VCU, SB, CM or LM). The highest intestinal parasite concentration was detected in the mucosa (VCU), with scores ranging from 3 to $4(+++$ to ++++$)$ in at least three dogs (dogs 1, 2 and 4). The submucosa and the smooth muscle layers of these organs were positive only in three dogs, and these had low parasite loads (score $1 ;+$ ). In addition, there were also many amastigotes in the Peyer's patches of the duodenum in one dog.

In the ileum, the parasite was recorded in $62.5 \%$ (5/8) of the dogs, with abundant parasites in the lamina propria of the mucosa. However, this was not the most intensely infected intestinal segment, except for the mucosa of dog no. 1 , which had the highest score (score $4 ;++++)$ for intramacrophagic amastigotes (Table 1 ). 
Table 1. Result of parasite burden in intestinal tissues (duodenum, jejunum, ileum and colon) from dogs infected with CVL and with intestinal Leishmania infantum amastigote (G1 group). Ilha Solteira, SP, Brazil, 2015.

\begin{tabular}{|c|c|c|c|c|c|}
\hline \multicolumn{6}{|c|}{ Parasite burden of Leishmania infantum amastigotes in intestinal tissues from dogs with CVL (G1) } \\
\hline \multirow{2}{*}{ Dogs } & \multirow{2}{*}{ Tissues } & \multirow{2}{*}{ Mucosa (villus/crypt) } & \multirow{2}{*}{ Submucosa } & \multicolumn{2}{|c|}{ Smooth muscle } \\
\hline & & & & Circular & Longitudinal \\
\hline \multirow{4}{*}{01} & $\mathrm{D}$ & ++++ & + & $\mathrm{N}$ & $\mathrm{N}$ \\
\hline & $\mathrm{J}$ & +++ & + & + & $\mathrm{N}$ \\
\hline & I & ++++ & ++ & + & $\mathrm{N}$ \\
\hline & $\mathrm{C}$ & +++ & ++ & $\mathrm{N}$ & $\mathrm{N}$ \\
\hline \multirow{4}{*}{02} & $\mathrm{D}$ & +++ & + & + & + \\
\hline & $\mathrm{J}$ & +++ & + & ++ & + \\
\hline & I & ++ & + & ++ & + \\
\hline & $\mathrm{C}$ & +++ & + & $\mathrm{N}$ & $\mathrm{N}$ \\
\hline \multirow{4}{*}{03} & $\mathrm{D}$ & $\mathrm{N}$ & $\mathrm{N}$ & $\mathrm{N}$ & $\mathrm{N}$ \\
\hline & $\mathrm{J}$ & $\mathrm{N}$ & $\mathrm{N}$ & $\mathrm{N}$ & $\mathrm{N}$ \\
\hline & I & + & + & $\mathrm{N}$ & $\mathrm{N}$ \\
\hline & C & $\mathrm{N}$ & $\mathrm{N}$ & $\mathrm{N}$ & $\mathrm{N}$ \\
\hline \multirow{4}{*}{04} & $\mathrm{D}$ & +++ & + & + & $\mathrm{N}$ \\
\hline & $\mathrm{J}$ & ++ & + & $\mathrm{N}$ & $\mathrm{N}$ \\
\hline & I & +++ & ++ & $\mathrm{N}$ & $\mathrm{N}$ \\
\hline & $\mathrm{C}$ & ++++ & ++ & $\mathrm{N}$ & $\mathrm{N}$ \\
\hline \multirow{4}{*}{05} & $\mathrm{D}$ & $\mathrm{N}$ & $\mathrm{N}$ & $\mathrm{N}$ & $\mathrm{N}$ \\
\hline & $\mathrm{J}$ & ++ & + & $\mathrm{N}$ & $\mathrm{N}$ \\
\hline & I & $\mathrm{N}$ & $\mathrm{N}$ & $\mathrm{N}$ & $\mathrm{N}$ \\
\hline & C & ++ & + & $\mathrm{N}$ & $\mathrm{N}$ \\
\hline \multirow{4}{*}{06} & $\mathrm{D}$ & $\mathrm{N}$ & $\mathrm{N}$ & $\mathrm{N}$ & $\mathrm{N}$ \\
\hline & $\mathrm{J}$ & $\mathrm{N}$ & $\mathrm{N}$ & $\mathrm{N}$ & $\mathrm{N}$ \\
\hline & I & $\mathrm{N}$ & $\mathrm{N}$ & $\mathrm{N}$ & $\mathrm{N}$ \\
\hline & C & +++ & $\mathrm{N}$ & $\mathrm{N}$ & $\mathrm{N}$ \\
\hline \multirow{4}{*}{07} & $\mathrm{D}$ & ++ & ++ & $\mathrm{N}$ & $\mathrm{N}$ \\
\hline & $\mathrm{J}$ & $\mathrm{N}$ & $\mathrm{N}$ & $\mathrm{N}$ & $\mathrm{N}$ \\
\hline & I & ++ & ++ & $\mathrm{N}$ & $\mathrm{N}$ \\
\hline & C & $\mathrm{N}$ & $\mathrm{N}$ & $\mathrm{N}$ & $\mathrm{N}$ \\
\hline \multirow{4}{*}{08} & $\mathrm{D}$ & $\mathrm{N}$ & $\mathrm{N}$ & $\mathrm{N}$ & $\mathrm{N}$ \\
\hline & $\mathrm{J}$ & $\mathrm{N}$ & $\mathrm{N}$ & $\mathrm{N}$ & $\mathrm{N}$ \\
\hline & I & $\mathrm{N}$ & $\mathrm{N}$ & $\mathrm{N}$ & $\mathrm{N}$ \\
\hline & $\mathrm{C}$ & +++ & $\mathrm{N}$ & $\mathrm{N}$ & $\mathrm{N}$ \\
\hline
\end{tabular}

$\mathrm{D}$ = Duodenum; J = Jejunum; I = Ileum; C = Colon; (+): Positive; (N): Negative.

In the colon, $75 \%(6 / 8)$ of the dogs were positive and had parasite load ranging from intense (score $3 ;+++$ ) to very intense (score 4; ++++). In this intestinal segment (colon), amastigotes were observed both outside and inside macrophages, and preferentially in the lamina propria of the mucosa near the basal region (crypt). However, amastigotes of $L$. infantum were not detected in the muscle layers of the colon.

\section{Microscopic alterations in the intestinal mucosa with}

\section{L. infantum}

By immunohistochemistry, the amastigotes of L. infantum were identified as a brown color (Figure 1). Numerous intramacrophagic amastigotes were seen in the lamina propria (dog no. 1) (Figure 1A, B) and also underneath the basal lamina at the tips of the villi (Figure 1C, D) of the ileum. A few immunostained amastigotes 

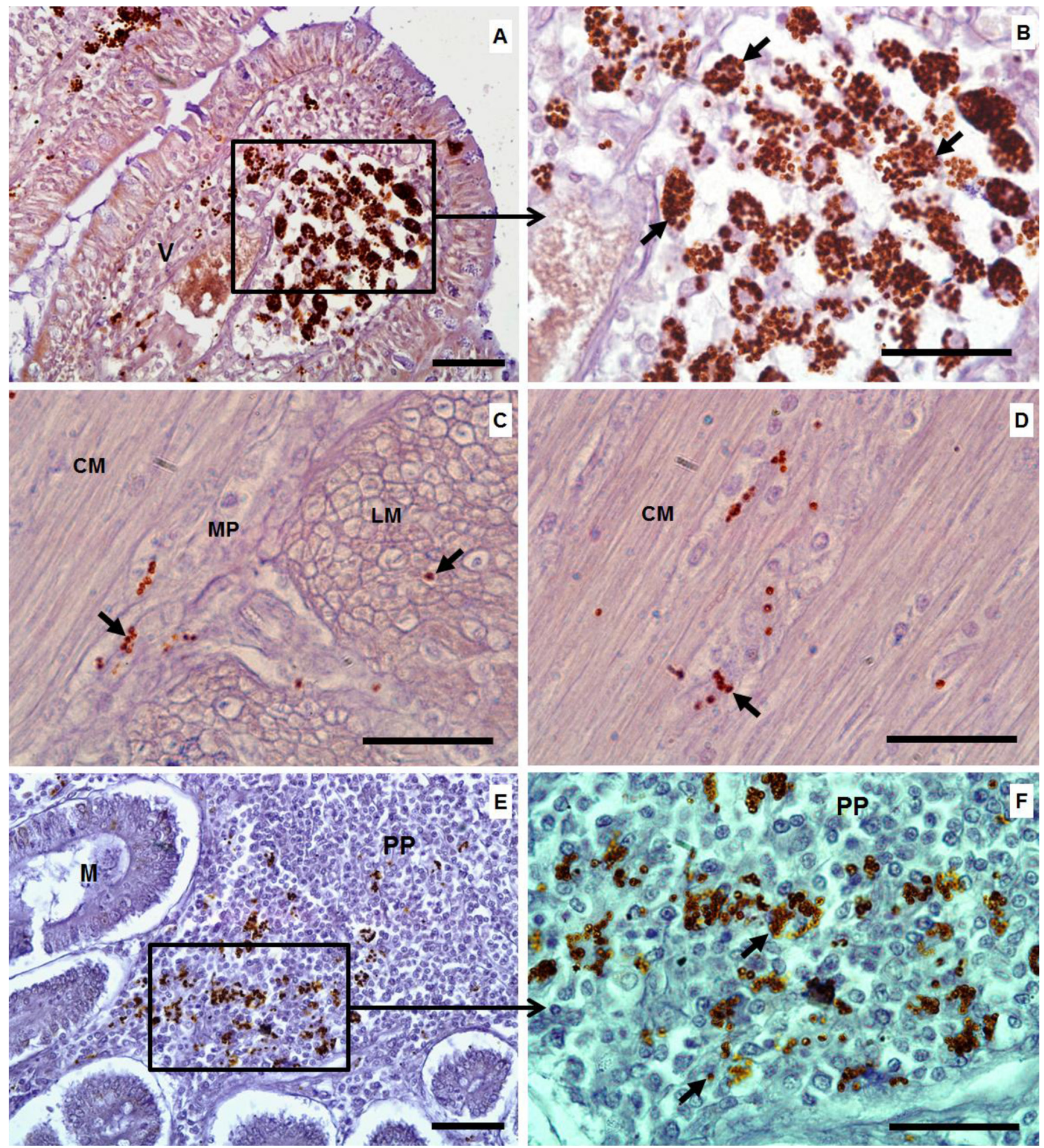

Figure 1. Histological sections from the intestine of dogs with CVL. A: (ileum) numerous macrophages filled with amastigotes of Leishmania infantum in the lamina propria at the tips of villi (objective lens: 40x): B: higher microscopic magnification of the tips of the villi (black arrows) showing more details of the amastigotes in the lamina propria and underneath the basal lamina of the epithelial layer (objective lens: 100×). C and D: (jejunum) note L. infantum amastigotes (small black arrows) present in the circular and longitudinal smooth muscle layers between the muscle fibers or inside the myenteric nervous plexus in jejunum tissues (objective lens: 100×). E: (duodenum) showing amastigote forms (black arrows) inside Peyer's patches (objective lens: 40×): F: higher magnification of Peyer's patches showing more details of the parasites (black arrows) (objective lens: $100 \times$ ). V = villus; $\mathrm{CM}=$ circular smooth muscle; $\mathrm{LM}=$ longitudinal smooth muscle; $\mathrm{MP}=$ myenteric nervous plexus; PP = Peyer's patches; Staining = immunohistochemistry. Bars = $50 \mu \mathrm{m}$. Ilha Solteira, SP, Brazil, 2015. 

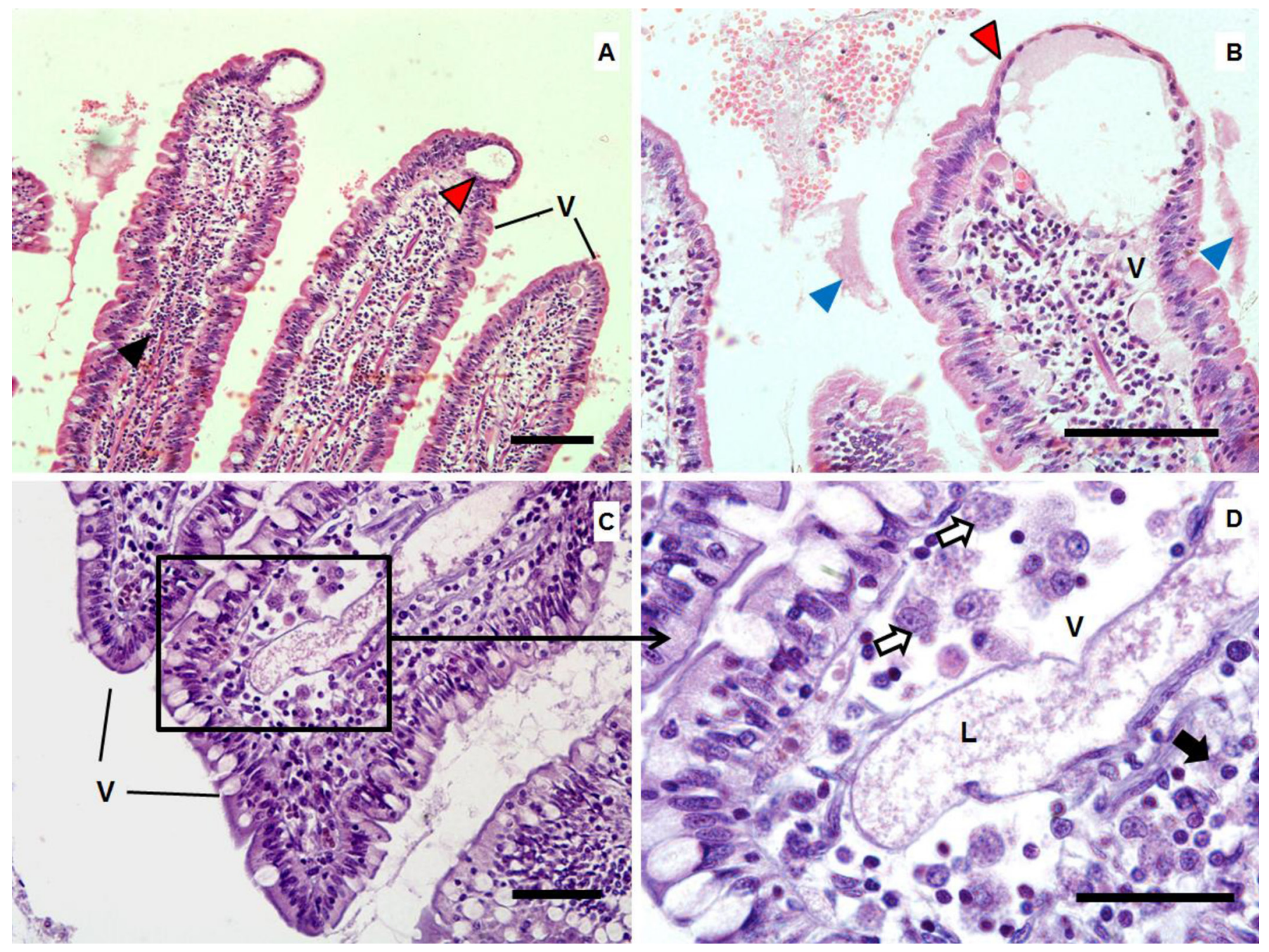

Figure 2. Histological sections from the intestinal tissues of dogs with CVL. A: (duodenum) note mononuclear cell infiltrate at the tips of the epithelial layer of the villi, with moderate microvacuoles, and apical edema similar to lymphangiomatous polyps (red arrow); also note the flattened columnar epithelial cells and the abundant lymphocytic infiltrate (black arrowhead) (objective lens: 20x). B: (duodenum) denudation of the epithelium (blue arrowhead). C: (ileum) tips of the villi with many macrophages (black rectangle) infected with Leishmania infantum amastigotes (objective lens: 40x). D: higher magnification of image C (objective lens: 100x) showing more details of infected macrophages (white arrows) and lymphocytes (black arrows); also note enlarged lymphatic vessels at the tips of the villi. $\mathrm{V}=$ villus; $\mathrm{L}=\mathrm{lymphatic}$ vessel. Staining: HE. Bars $=50 \mu \mathrm{m}$. Ilha Solteira, SP, Brazil, 2015.

were also noted in the submucosa and around the muscle fibers or in the myenteric nervous plexus of the circular and longitudinal smooth muscle layers of the jejunum (Figure 1C, D). In addition, parasites were present within Peyer's patches (Figure 1E, F).

The duodenum infected with amastigotes presented mucosal structural alterations where the parasites were found at the highest concentration. Dog no. 1, with a parasite load of score $4(++++)$ (Table 1), presented mononuclear cellular infiltrate at the tips of the villi, containing microvacuoles, and apical edema similar to lymphangiomatous polyps (Figure 2A, B), with absence of columnar epithelial cells, including a denudation of the epithelium at this site (Figure 2B). The submucosa of the duodenum, even only slightly infected (score $1 ;+$ ), was enlarged and showed disorganization of the connective fibers and increased numbers of blood vessels (arterioles). Three dogs (37.5\%) presented parasites in the smooth muscle layers of the duodenum, both in longitudinal and in circular layers.

The jejunum had lower parasite burden than the duodenum (Table 1). In this intestinal segment, the Brunner glands were surrounded by infiltration not only of mononuclear cells (with predominance of macrophages), but also of polymorph nuclear cells. Dog no. 3 had Peyer's patches of the jejunum and duodenum with large hypertrophic secondary follicles, thereby suggesting that intense activity of antibody secretion had occurred as an immune response against parasites present inside or outside Peyer's patches in the intestinal mucosa.

The ileum was less infected with amastigotes than the other intestinal segments, but two dogs were very intensely infected (dogs 1 and 4) (Table 1). In dog 1, an abundance of parasites was noted at the tips of the villi in many hypertrophic macrophages, 


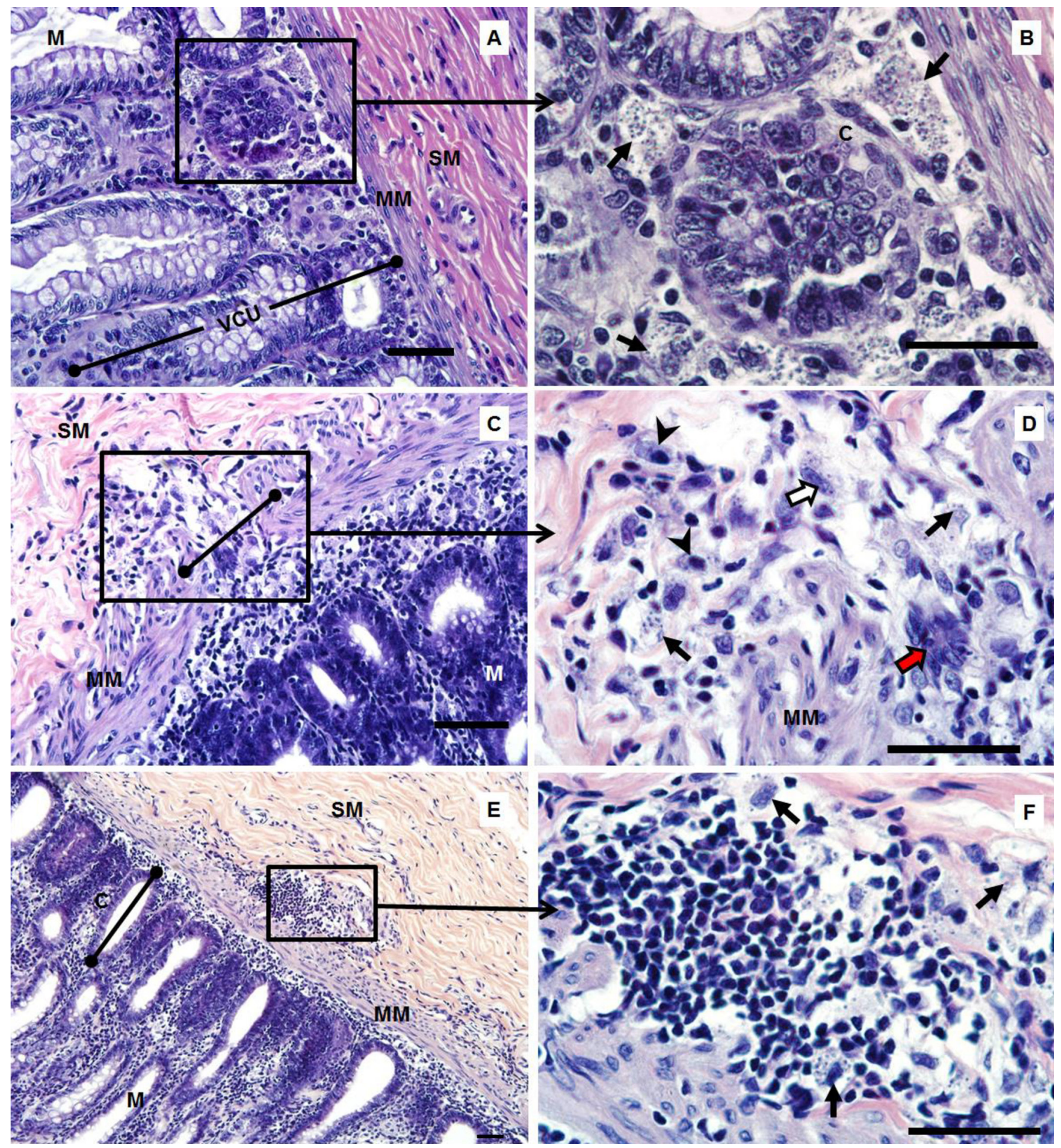

Figure 3. Histological sections from the intestinal tissues (colon) of dogs with CVL showing intense inflammatory reaction with predominance of mononuclear cells, particularly macrophages, lymphocytes and plasma cells, and the presence of amastigote forms of Leishmania infantum. A: at the basal crypt (objective lens: $40 \times$ ). B: higher magnification of image A (objective lens: 100x) showing greater details of the black square (image A), with numerous amastigotes inside and outside the hypertrophic macrophages (small black arrows) and an atrophic crypt. C: infiltration of inflammatory cells at the crypt of the mucosa and cell infiltration through the muscle mucosa and submucosa (SM) (black rectangle) (objective lens: 20x). D: higher magnification of image C (objective lens: 100x), showing amastigote forms (small black arrows), macrophages filled with parasites (white arrows), mononuclear cell infiltration (black arrowheads) and giant cells (red arrow). E: chronic granulomatous inflammatory reaction in the submucosa (black square) (objective lens: 20x). F: higher magnification of image E (objective lens: 100x), showing predominance of mononuclear cells and infected macrophages (small black arrows). $\mathrm{M}=$ mucosa; $\mathrm{SM}=$ submucosa; VCU = villus-crypt unit; $\mathrm{C}=$ crypt; $\mathrm{Mm}=$ muscle mucosa; Staining = HE. Bars = $50 \mu \mathrm{m}$. Ilha Solteira, SP, Brazil, 2015. 
occupying practically the entire space of the lamina propria. The lacteal vessels of the ileum were greatly enlarged, but the parasites were not seen inside. Some lymphocytes and plasmocytes were also present, but the cellular inflammatory infiltrate was basically constituted by macrophages (Figure 2C, D). Despite the abundance of parasites observed at the tips of the villi and even just beneath the basal lamina, the epithelial layer presented physical integrity at these locations.

In the colon, parasites were easily detected in all dogs, exception only for animals 3 and 7 (Table 1). In the crypts, there were abundant mononuclear cells (macrophages), infected with abundant parasites (Figure 3A, B). The submucosa of the colon showed a granulomatous inflammatory reaction, represented by mononuclear cells such as lymphocytes, plasma cells, hypertrophic macrophages, giant cells and parasites (Figure 3C-F). In addition, discontinuity of the muscularis mucosa was also observed in some places, which could favor invasion of inflammatory cells and parasites into the submucosa, or vice versa (Figure 3C, D).

Amastigotes were not seen in the smooth muscle layers of the colon in any of the dogs examined.

Polymorphic nuclear cell (PMN) hyperplasia, mucosal congestion, hemorrhagic areas in the intestinal wall and liquid or bloody stools in the luminal content were observed in some infected dogs. Hemorrhagic areas were observed in 30\% (6/20) of the tissue samples: frequently in dogs from G2 group (44.4\%; 4/9) followed by the dogs from G1 (25\%; 2/8). Dog no. 8 from G1 group, which had score $3(+++)$, presented hemorrhagic areas in the mucosa, submucosa and muscle. Congestion areas were seen in $7 / 9(77.7 \%)$ dogs from G2 group, but only in 2/8 (25\%) from G1 group. In contrast, a mononuclear reaction was observed in $87.5 \%(7 / 8)$ of the dogs from G1, and in $55.5 \%(5 / 9)$ of the dogs from G2. In G1, 87.5\% (7/8) and 62.5\% (5/8) of the dogs had mononuclear cellular infiltration in the small and large intestines, respectively.
Most of the dogs from G1 group had no diarrhea or severe macroscopic alterations such as hemorrhagic enteritis in the intestinal layers of the mucosa, particularly dogs with high intestinal Leishmania parasite loads (dogs 1, 2, 4, 6 and 9). In contrast, two dogs (3 and 5) with hemorrhagic enteritis and diarrhea had low intestinal parasite loads (Table 1).

\section{Microscopic alterations in the intestinal mucosa with L. infantum}

The variables used in the comparison analyses were the clinical signs (CS), body score (BS), macroscopic (MaA) and microscopic structural alterations $(\mathrm{MiA})$ of the intestinal wall of the duodenum, jejunum, ileum and colon.

Comparison analyses on these variables were done with dogs from G1, G2 and G3 groups. As shown in Table 2, except for the variable $\mathrm{MaA}$ in the colon, most of the variables studied in the dogs of G1 (with intestinal amastigotes) were statistically different from G3 (control), both for the small intestine and for the large intestine. In contrast, the dogs in G2 remained in an intermediate category, except for the clinical signs, for which the dogs in G2 showed no significant difference in comparison with G1 and G3.

The MaA scores ranged from 1 to 2 in the most of cases in the dogs from G1 group, with apparently normal intestinal walls or slightly injured, even infected with amastigotes, while the dogs in G2 and G3 remained with score 1. Even though the variable MaA was mild in G1, it was significantly higher than in G3 in the small intestine, but not in G2. However, in the colon, the differences were not significant among these three groups.

The microscopic structural alterations (MiA) in G1 ranged from moderate to severe with scores significantly higher in comparison with G3 not only in the small, but also in the large intestines. In the dogs of $\mathrm{G} 2$, the MiA scores ranged from mild to moderate, but not statistically significant from G3 group (Table 2).

Table 2. Comparative analysis among dogs from G1 group (infected with CVL and with intestinal Leishmania infantum amastigotes), G2 group (infected with CVL, but without intestinal amastigotes) and G3 group (uninfected control group) in relation to different variable scores (clinical signs variables, macro and microscopic structural alterations and corporal scores). Ilha Solteira, SP, Brazil, 2015.

\begin{tabular}{|c|c|c|c|c|}
\hline \multicolumn{5}{|c|}{ Median values of score of the different variables analyzed in the dogs } \\
\hline \multirow{2}{*}{ Variables } & \multicolumn{3}{|c|}{ Groups of Dogs } & \multirow{2}{*}{$\begin{array}{c}\text { p-value } \\
\text { Kruskal-Wallis }\end{array}$} \\
\hline & G1 & G2 & G3 & \\
\hline CS & $3.25^{a}$ & $2.66^{\mathrm{ab}}$ & $1.33^{b}$ & 0.008748 \\
\hline BS & $3^{a}$ & $3^{a}$ & $1.33^{b}$ & 0.006429 \\
\hline MaA-D & $2^{\mathrm{a}}$ & $1.44^{\mathrm{ab}}$ & $1^{b}$ & 0.006085 \\
\hline MaA-J & $2.25^{\mathrm{a}}$ & $1.44^{\mathrm{ab}}$ & $1^{\mathrm{b}}$ & 0.00226 \\
\hline MaA-I & $2.12^{\mathrm{a}}$ & $1.77 \mathrm{ab}$ & $1^{\mathrm{b}}$ & 0.004401 \\
\hline $\mathrm{MaA}-\mathrm{C}$ & $1.87^{\mathrm{a}}$ & $1.66^{\mathrm{a}}$ & $1^{\text {a }}$ & 0.07353 \\
\hline MiA-D & $2.75^{a}$ & $2^{a b}$ & $1^{\mathrm{b}}$ & 0.005496 \\
\hline MiA-J & $2.62^{a}$ & $2^{a b}$ & $1^{b}$ & 0.01417 \\
\hline MiA-I & $2.62^{a}$ & $2.3^{\mathrm{ab}}$ & $1^{\mathrm{b}}$ & 0.03425 \\
\hline MiA-C & $2.87^{a}$ & $1.77^{a b}$ & $1^{b}$ & 0.002115 \\
\hline
\end{tabular}

Note: $\mathrm{CS}$ = clinical sign scores; $\mathrm{BS}=$ body scores; $\mathrm{MaA}=$ macroscopic structural alterations scores; MiA = microscopic structural alteration scores; $\mathrm{D}=$ duodenum; $\mathrm{J}=$ jejunum; I = ileum; C = colon. Confidence interval of 95\% ( $\mathrm{p} \leq 0.05)$. Kruskal-Wallis and Bonferroni test. Different lowercase letters (a and b) significant differences between columns at $5 \%$. 
Table 3. Estimates of the Spearman correlation coefficient of different variables (parasite burden, clinical signs, macro and microscopic structural alterations and corporal scores) in dogs infected with CVL and with intestinal Leishmania infantum amastigotes (G1). Ilha Solteira, SP, Brazil, 2015.

\begin{tabular}{cccc}
\hline & Correlation analysis between variables & \\
\hline Variables & Small Intestines & Large Intestines & General \\
\hline PI x CS & $0.73^{*}$ & 0.41 & 0.46 \\
PI x BS & 0.16 & -0.12 & 0.16 \\
PI x MaA & $0.72^{*}$ & -0.41 & 0.56 \\
PI x MiA & $0.81^{*}$ & $0.78^{*}$ & $0.82^{*}$ \\
MaA x CS & 0.55 & 0.02 & 0.42 \\
MiA x CS & $0.83^{*}$ & $0.72^{*}$ & $0.83^{*}$ \\
MaA x BS & 0 & 0.58 & 0.53 \\
MiA x BS & 0.21 & 0 & 0.21 \\
\hline
\end{tabular}

Note: $\mathrm{PI}$ = parasite intensity scores; $\mathrm{CS}=$ clinical signs scores; $\mathrm{BS}$ = body scores; $\mathrm{MaA}=$ macroscopic structural alteration scores; $\mathrm{MiA}=$ microscopic structural alteration scores. Linear correlation coefficient of Spearman $(\mathrm{rs}) .\left({ }^{*}\right)$ significance of $5 \%(\mathrm{p} \leq 0.05)$.

Dogs of G1 showed significant positive correlations between intestinal parasite burden $(\mathrm{PB})$ and $\mathrm{MiA}$ in the small intestine ( $\mathrm{rs}=0.81 ; \mathrm{p}=0.015)$ and in the large intestine ( $\mathrm{rs}=0.78$; $\mathrm{p}=0.023)$, meaning that when the numbers of parasites increase, the mucosal alteration intensify (Table 3 ).

The correlation analysis between the clinical signs and the $\mathrm{PB}$ was positive and significant ( $\mathrm{rs}=0.73 ; \mathrm{p}=0.041$ ) in the small intestine, but not in the large intestine (colon) (Table 3). The clinical signs and MiA also showed positive correlations in the small intestine (ileum) and large intestine (colon), with respective values of $\mathrm{rs}=0.83 ; \mathrm{p}=0.011$ and $\mathrm{rs}=0.72 ; \mathrm{p}=0.042)$ (Table 3$)$.

\section{Discussion}

In the previous works, the presence of amastigotes of $L$. infantum has been described in gastrointestinal tissues of dogs infected with CVL, particularly in the mucosa of cecum and colon where the parasites were detected in higher burden (KEENAN et al., $1984 \mathrm{a}$, b; GONZÁLEZ et al., 1990; ADAMAMA-MORAITOU et al., 2007; PINTO et al., 2011; FIGUEIREDO et al., 2013). In the present work, macrophages containing $L$. infantum amastigotes were also found in the large (colon) and in the small intestines (duodenum, jejunum and ileum) with a mononuclear inflammatory infiltration, represented mainly by macrophages, lymphocytes and plasma cells in the majority of the cases of infected dogs from G1 group. The prevalence of dogs with intestinal leishmaniasis was $87.5 \%$ and $62.5 \%$, respectively in the small and large intestine, meaning that the small intestine walls can be similarly infected with Leishmania amastigotes. More recently, Pinto et al. (2013) reported one asymptomatic dog infected with CVL with high parasite load in the duodenum and suggested the existence of different regulatory mechanism in this intestinal segment. However, Figueiredo et al. (2013) showed that the colon harbored more parasites than the jejunum and the cellular expression of TLR2 (Toll Like Receptor) and IL-4 were more evidenced in colon than in the jejunum, whileTLR9-expressing cells, IL-10 and TNF- $\alpha$ were more frequent in jejunum than in colon. The authors suggested a protective immunity against the parasite in the jejunum, but the establishment of the disease in the colon. However, the results should be interpreted with caution and more studies need to be done, because the small intestines can also harbor high numbers of parasites as we detected in this work as well as in another publication (PINTO et al., 2013).

In the small intestines of dogs from G1 group, abundant infected macrophages with $L$. infantum amastigotes occupying the lamina propria in the tips of the villi, just below to the epithelial layer with evident microscopic morphological alterations were seen in the ileum of one dog. In the same dog, denudation of the epithelium and lymphangiomatous polyps were observed at the tips of the villi of the duodenum in association with severe inflammatory mononuclear infiltrate and high parasite burden. This association between lymphangiomatous polyps and intestinal leishmaniasis was a novel feature of the present study, although Silva et al. (2002) reported polyp like formation in the intestinal mucosa of dogs affected by CVL.

In addition, our study showed and described the presence of moderate amount of amastigotes of this parasite in the circular and longitudinal smooth muscle layers (particularly associated with the myenteric nervous plexus) of the small intestines, seen in $37.5 \%(3 / 8)$ of the dogs.

In the colon, $L$. infantum amastigotes were seen in hypertrophic macrophages in the lamina propria of the crypts mainly near to the muscularis mucosa and in the submucosa. The parasites were associated with chronic mononuclear inflammatory infiltrate represented by lymphocytes, macrophages and giant and epithelioid cells, in agreement with previous papers (FERRER et al., 1991; PINTO et al., 2011, 2013). In the submucosa, a mild chronic granulomatous inflammatory reaction represented particularly by infected macrophages was also present in the colon in one dog. Through the colonoscopy procedures, Adamama-Moraitou et al. (2007) observed pyogranulomatous reactions as the most common histological characteristic in the mucosa of the colon of dogs.

In cases of experimental infection, González et al. (1990) observed a severe chronic inflammatory process in the mucosa and submucosa of the colon and rectum of dogs. As a result, focal micro-erosions developed in the mucosal surface, thereby reducing the area of the large bowel available for water absorption and causing diarrhea. Moreover, Ferrer et al. (1991) and 
Adamama-Moraitou et al. (2007) reported occurrences of erosive and ulcerative colitis in association with severe clinical signs of leishmaniasis in naturally infected dogs. However, in the present work, despite enlargement of the lamina propria due to severe inflammatory mononuclear infiltrate and intense parasite load in dogs from G1 group, most of them presented physical integrity of the epithelium layer, without severe morphological structural alterations such as epithelial micro erosion or cell destruction in the intestinal mucosa. The high parasite burden in the mucosa of the colon with only mild pathological alterations led Pinto et al. (2011) to suggest that L. infantum might gain advantage from the intestinal immunoregulatory response (immunological tolerance). Lymphocyte T regulatory cells (Tregs) could be mediating this kind of immunoregulatory response. More recently, Figueiredo et al. (2014) inferred that Treg (FoxP3) cell expression was not only mediated by intestinal leishmaniasis, but may also participate in the homeostasis of the colon under normal physiological condition. These controversial reports indicate that still need further studies to elucidate important immune mechanism related with this parasite in the intestinal wall.

Chronic large bowel diarrhea is very uncommon as the primary clinical sign of canine leishmaniasis (SLAPPENDEL, 1988). In agreement, most of the dogs from G1 group had no diarrhea and did not show any severe histopathological alterations in the mucosa, in spite of their high parasite load in the small or large intestines. However, it is important to mention that two dogs $(20 \%)$ positive for intestinal amastigotes were suffering with bloody diarrhea, but the intensity of parasite load was low. In these two animals, we also noted a polymorphic nuclear (PMN) cellular infiltration represented by eosinophils and neutrophils in the intestinal wall. This was indicative of acute rather than the chronic inflammation that was observed in the most of dogs with high parasite burden. Diarrhea had already been reported in dogs affected with leishmaniasis, but in these cases the animals showed other systemic signs, including anorexia, emaciation, anemia, lymphadenopathy and skin lesions (CHAPMAN \& HANSON, 1984). Furthermore, González et al. (1990) and Ferrer et al. (1991) reported cases of chronic colitis and diarrhea in dogs that were naturally infected with L. infantum. However, Ferrer et al. (1991) questioned whether Leishmania spp caused these conditions or whether they were incidental findings, which would be particularly relevant if the parasite load was low. They concluded that there was no evidence of any definitive pathogenic correlation between CVL and chronic colitis. Corroborating this idea, Adamama-Moraitou et al. (2007) mentioned that it is important to consider clinical signs or inflammatory reactions that are comparable with other infections, including bacteria or parasites (protozoa and helminths), before making a diagnosis. However, the dogs of the present work were not co-infected with gastrointestinal helminths or other protozoans that could contribute for other immune cellular changes in the lamina propria.

While dogs from G1 group had a cellular response marked mainly by larger numbers of lymphocytes, plasma cells and macrophages, dogs from G2 group (without parasites) had larger hemorrhagic and congestion areas and greater predominance of PMN cells than the dogs in G1. In contrast, Figueiredo et al. (2013) described circulatory alterations such as hemorrhage and congestion and low numbers of neutrophils and eosinophils associated with a diffuse mononuclear cellularity in the large and small intestines, only in dogs infected with the parasite, but without statistical difference between symptomatic and asymptomatic dogs. Toplu \& Aydogan (2011) found in the small and large intestines a mild to severe mononuclear cell infiltrations, including eosinophils in lamina propria and muscularis mucosa of the intestines from $77 \%$ of dogs with CVL, but only $9 \%$ of these dogs had intestinal amastigotes. Because of this no correlation data between histological changes and parasite density in the intestines, Toplu \& Aydogan (2011) suggested a possible immune-complex reactions as the main reason for chronic alterations in the intestinal tissues without the parasites. Taken this in consideration, it could be a reason for inflammatory reaction detected in intestinal tissues of dogs from G2 group, with CVL, but without the amastigotes in the intestines.

The variables CS (clinical signs), BS (body score), microscopic (MiA) and macroscopic (MaA) structural alterations of the dogs from G1, G2 and G3 groups were used in a comparative analysis. This analysis showed that the dogs from G1 group differed from G3, but not from G2 group, in the majority of the variables, except for macroscopic structural alteration of the colon, for which there were no differences in any group.

The variable $\mathrm{MiA}$ in the small and large intestines ranged from moderate to severe in the dogs of G1 and demonstrated significant differences in comparison with G3. These results suggested that the parasites in G1 were responsible for some of the microscopic alterations in the intestinal mucosa. In addition, the parasite burden of the amastigotes (G1 group) in the small as well as in the large intestines was positively and significantly correlated with the microscopic structural alterations (MiA) observed in the intestinal wall of these dogs, thus providing strong evidence that the parasites were the cause of this histopathological finding. This variable ( $\mathrm{MiA})$ in the small and large intestines was also correlated with the clinical signs of the dogs with CVL. However, no correlations was found between the dogs with and without detected colonic parasitism and the sex, age, or type of diet of these animals (ADAMAMA-MORAITOU et al., 2007) Furthermore, no correlation was also found between clinical signs and pathological, immunological, and parasitological findings in gastrointestinal tissues from dogs with CVL (FIGUEIREDO et al., 2014). These positive correlation found in this work, may be predictive that dogs with high scores for systemic clinical signs, particularly in advanced stages of the disease can also present amastigotes in the intestines, thereby intensifying the overall clinical status of the disease.

However, there was no correlation between the parasite burden and body score, demonstrating that the emaciation observed in dogs of G1 may be much more as a result of the general systemic clinical aspects of CVL than necessarily about the presence of parasites in the intestinal mucosa. CVL is a chronic systemic disease and, for that reason, immunosuppressed infected dogs are more susceptible to other infectious agents that compromise the immune system (GONTIJO \& MELO, 2004). These may lead the dogs to progressive weight loss, emaciation and death, in agreement with the idea that immunosuppression favors dissemination of the parasite to different organs, including the intestines. Even though the presence of the parasite in the intestine is not the determining 
factor for weight loss in dogs, it may indirectly be responsible for exacerbation of the disease, thereby leading to microscopic structural alterations in the intestinal mucosa that affect food digestion and weight loss.

The dogs with intestinal amastigotes of L. infantum (G1) showed mild macroscopic structural alterations ( $\mathrm{MaA})$, or even absence of such alterations, and consequently there was no correlation with parasite burden in the mucosa of the small and large intestines. In addition, there was also a lack of correlation of clinical signs with MaA, which can be explained by the fact that macroscopic abnormalities in the intestinal mucosa, caused by the parasite, do not always correlate with the severity of the disease. Similarly, Ghinato et al. (2011) did not report any macroscopic alterations in the small and large intestines in dogs with intestinal amastigotes. In the large intestine, the correlation between parasite burden and MaA was negative ( $\mathrm{rs}=-0.41$ ), meaning that the lesions caused by the parasite in the mucosa were only at the microscopic level, and thus demonstrating possible regulatory control of the immune response in favor of the parasite. In contrast, Adamama-Moraitou et al. (2007) found a positive correlation only between colonic parasitism with macroscopical mucosal lesions in the colon, probably showing that the former was closely associated with the pathogenesis. The prevalence of Leishmania spp. parasitism in the colonic mucosa of dogs with symptomatic CVL, but without overt colitis implies the inclusion of intestinal leishmaniasis in the list of differentials canine chronic colitis, at least in endemic areas (ADAMAMA-MORAITOU et al., 2007).

\section{Conclusions}

This study recorded the L. infantum amastigotes in all layers of the small and large intestines of dogs with CVL with greater predominance in the lamina propria (crypts and villi) causing mononuclear cell hyperplasia, with predominance of macrophages. In addition, this study described the occurrence of $L$. infantum amastigotes in the muscle layer of the small intestine meaning that the parasite had free access to all layers of the intestinal tract.

The positive correlation between the intestinal parasite burdens with microscopic structural alterations in intestinal mucosa suggests that the parasite may be responsible for the inflammatory reactions observed in the mucosa of these organs and could contribute for impairing of the food digestion or the nutrients absorption mechanism aggravating the clinical status of the dogs with CVL.

The body score not correlated with the parasite burden in the intestine indicated that the emaciation of the animals could be caused by other factors related with the systemic clinical aspects of the CVL, but not necessarily with the parasite in the intestines.

\section{Acknowledgements}

The authors thank the Brazilian Research Funding Agency FAPESP for its financial support (no 2013/13875-5) and the Zoonotic Disease Control Center (ZCC) of Ilha Solteira, SP, for donating the biological materials from the dogs.

\section{References}

Adamama-Moraitou KK, Rallis TS, Koytinas AF, Tontis T, Plevraki $\mathrm{K}$, Kritsepi M. Asymptomatic colitis in naturally infected dogs with Leishmania infantum: a prospective study. Am J Trop Med Hyg 2007; 76(1): 53-57. PMid:17255229.

Alvar J, Cañavate C, Molina R, Moreno J, Nieto J. Canine leishmaniasis. Adv Parasitol 2004; 57: 1-88. http://dx.doi.org/10.1016/S0065308X(04)57001-X. PMid:15504537.

Assis J, Queiroz NMGP, Silveira RCV, Nunes CM, Oliveira TMFS, Noronha ACF Jr, et al. Estudo comparativo dos métodos diagnósticos para Leishmaniose Visceral em cães oriundos de Ilha Solteira, SP. Rev Bras Parasitol Vet 2010; 19(1): 17-25. http://dx.doi.org/10.4322/ rbpv.01901004. PMid:20385055.

Blavier A, Keroack S, Denerolle P, Goy-Thollot I, Chabanne L, Cadore JL, et al. Atypical forms of canine leishmaniosis. Vet J 2001; 162(2): 108-120. http://dx.doi.org/10.1053/tvjl.2000.0556. PMid:11531395.

Chang KP, Fong D, Bray RS. Biology of Leishmania and leishmaniasis. In: Chang KP, Bray RS. Leishmaniasis. Amsterdam: Elsevier Science Publishers; 1985. p. 1-30.

Chapman W, Hanson W. Leishmaniasis. In: Greene C. Clinical Microbiology and Infectious disease of the dog and cat. Philadelphia: W.B. Saunders; 1984. p. 764-770.

Chiapella A. Diagnosis and management of chronic colitis in the dogs and cat. In: Kirk R. Current Veterinary Therapy: IX Small Animal Practice. Philadelphia: W.B. Saunders; 1986. p. 896-993.

Ciaramella P, Oliva G, De Luna R, Gradoni L, Ambrosio R, Cortese $\mathrm{L}$, et al. A retrospective clinical study of canine leishmaniasis in 150 dogs naturally infected by Leishmania infantum. Vet Rec 1997; 141(21): 539-543. http://dx.doi.org/10.1136/vr.141.21.539. PMid:9413121.

Feitosa MM, Ikeda FA, Luvizotto MCR, Perri SHV. Aspectos clínicos de cães com leishmaniose visceral no município de Araçatuba, São Paulo, Brasil. Clin Vet (Milano) 2000; 5(28): 36-44.

Ferrer L, Juanola B, Ramos JA, Ramis A. Chronic colitis to Leishmania infection in two dogs. Vet Pathol 1991; 28(4): 342-343. http://dx.doi. org/10.1177/030098589102800414. PMid:1949514.

Figueiredo MM, Amorim IFG, Pinto AJW, Barbosa VS, Pinheiro LJ, Deoti B, et al. Expression of Toll-like receptors 2 and 9 in cells of dog jejunum and colon naturally infected with Leishmania infantum. BMC Immunol 2013; 14(1): 22. http://dx.doi.org/10.1186/1471-2172-14-22. PMid:23668673.

Figueiredo MM, Deoti B, Amorim IF, Pinto AJW, Moraes A, Carvalho $\mathrm{CS}$, et al. Expression of regulatory $\mathrm{T}$ cells in jejunum, colon, and cervical and mesenteric lymph nodes of dogs naturally infected with Leishmania infantum. Infect Immun 2014; 82(9): 3704-3712. http://dx.doi.org/10.1128/ IAI.01862-14. PMid:24935975.

Ghinato L, Maia FCL, Alves LC, Tafuri VL, Figueiredo MM, Torres $\mathrm{SM}$, et al. Alteraçóes estruturais e marcação imunohistoquímica do parasitismo no intestino de cães (Canis familiaris) (Linnaeus, 1758) naturalmente infectados por Leishmania (Leishmania) infantum (Nicolle, 1908). Med Vet 2011; 5(2): 9-13.

Gontijo CMF, Melo NM. Leishmaniose Visceral no Brasil: quadro atual, desafios e perspectivas. Rev Bras Epidemiol 2004; 7(3): 338-349. http:// dx.doi.org/10.1590/S1415-790X2004000300011. 
González JL, Fermin ML, Garcia P, Rollan E, Castaño M. Erosive colitis in experimental Canine Leishmaniasis. Zentralbl Veterinarmed B 1990; 37(5): 377-382. PMid:2396485.

González JL, Insa F, Novoa C, Pizarro M. Intestinal amyloidosis in hamsters with visceral leishmaniasis. Br J Exp Pathol 1986; 67(3): 353360. PMid:3718842.

Gordon HMCL, Whitlock HV. A new technique for counting nematode eggs in sheep feces. J Counc Sci Ind Res 1939; 12(1): 50-52.

Hoffman WA, Pons JA, Janer JL. The sedimentation concentration method in Schistosomiasis mansoni. J Public Health Trop Med 1934; 9: 283-291.

Keenan CM, Hendricks LD, Lightner L, Johnson A. Visceral Leishmaniasis in the German Shepherd dog. II. Pathology. Vet Pathol 1984a; 21(1): 80-86. PMid:6710817.

Keenan CM, Hendricks LD, Lightner L, Webster HK, Johnson A. Visceral Leishmaniasis in the German Shepherd dog. I. Infection, clinical disease, and clinical pathology. Vet Pathol 1984b; 21(1): 74-79. PMid:6710816.

Kuhls K, Alam MZ, Cupolillo E, Ferreira GEM, Mauricio IL, Oddone $\mathrm{R}$, et al. Comparative microsatellite typing of new world Leishmania infantum reveals low heterogeneity among populations and recent old world origin. PLoS Negl Trop Dis 2011; 5(6): e1155. http://dx.doi. org/10.1371/journal.pntd.0001155. PMid:21666787.

Miller HRP, Jarrett WHF. Immune reactions in mucous membranes. I. Intestinal mast cell response during helminth expulsion in the rat. Immunology 1971; 20(3): 277-288. PMid:5551353.

Oliveira TMFS, Furuta PI, Carvalho D, Machado RZ. A study of crossreactivity in serum samples from dogs positive for Leishmania sp., Babesia canis and Ehrlichia canis in enzyme-linked immunosorbent assay and indirect fluorescent antibody test. Rev Bras Parasitol Vet 2008; 17(1): 7-11. PMid:18554433.

Pinto AJW, Figueiredo MM, Ferreira RA, Caliari MV, Tafuri WL. Unusual Small Intestine inflamatory Lesions in a dog with visceral leishmaniasis. Braz J Vet Pathol 2013; 6(1): 19-25.

Pinto AJW, Figueiredo MM, Silva FL, Martins T, Michalik MSM, Tafuri WL, et al. Histopathological and parasitological study of the gastrointestinal tract of dogs naturally infected with Leishmania infantum. Acta Vet Scand 2011; 53(1): 67. http://dx.doi.org/10.1186/1751-014753-67. PMid:22166041.

Porrozzi R, Pereira MS, Teva A, Volpini AC, Pinto MA, Marchevsky $\mathrm{RS}$, et al. Leishmania infantum-induced primary and challenge infections in rhesus monkeys (Macaca mulatta): a primate model for visceral leishmaniasis. Trans R Soc Trop Med Hyg 2006; 100(10): 926-937. http:// dx.doi.org/10.1016/j.trstmh.2005.11.005. PMid:16455120.

Queiroz NMGP, Assis J, Oliveira TMFS, Machado RZ, Nunes CM, Starke-Buzetti WA. Canine Visceral Leishmaniasis diagnosis by immunohistochemistry and PCR in skin tissues in association with RIFI and ELISA-test. Rev Bras Parasitol Vet 2010; 19(1): 34-40. http://dx.doi. org/10.4322/rbpv.01901006. PMid:20385057.

Queiroz NMGP, Silveira RCV, Noronha ACF Jr, Oliveira TMFS, Machado RZ, Starke-Buzetti WA. Detection of Leishmania (L.) chagasi in canine skin. Vet Parasitol 2011; 178(1-2): 1-8. http://dx.doi.org/10.1016/j. vetpar.2010.12.033. PMid:21295916.

R Core Team. R: A language and enviroment for statistical computing [online]. Vienna: R Foundation for Statistical Computing; 2015 [cited 2015 Apr 12]. Available from: http://www.R-project.org/

Ross R. Note on the bodies recently described by Leishman and Donovan. BMJ 1903; 2(2237): 1261-1262. http://dx.doi.org/10.1136/ bmj.2.2237.1261. PMid:20761169.

Silva FL, Tafuri WL, Oliveira MR, Tafuri WL. Histopathological and immunohistochemical study of the gastrointestinal tract from a dog naturally infected with Leishmania (Leishmania) chagasi: a case report. Arq Bras Med Vet Zootec 2002; 54(4): 340-344. http://dx.doi.org/10.1590/ S0102-09352002000400002.

Slappendel RJ. Canine leishmaniasis: a review based on 95 cases in the Netherlands. Vet Q 1988; 10(1): 1-16. http://dx.doi.org/10.1080/0165 2176.1988.9694140. PMid:3287754.

Solano-Gallego L, Morell P, Arboix M, Alberola J, Ferrer L. Prevalence of Leishmania infantum infection in dogs living in an area of canine leishmaniasis endemicity using PCR on several tissues and serology. J Clin Microbiol 2001; 39(2): 560-563. http://dx.doi.org/10.1128/ JCM.39.2.560-563.2001. PMid:11158106.

Starke WA, Oaks JA. Ileal Mucosal mast cell, eosinophil, and goblet cell populations during Hymenolepis diminuta infection of the rat. $J$ Parasitol 2001; 87(5): 1222-1225. http://dx.doi.org/10.1645/00223395(2001)087[1222:IMMCEA]2.0.CO;2. PMid:11695409.

Tafuri WL, Oliveira MR, Melo MN, Tafuri WL. Canine visceral leishmaniosis: a remarkable histopathological picture of one case reported from Brazil. Vet Parasitol 2001; 96(3): 203-212. http://dx.doi.org/10.1016/ S0304-4017(00)00436-2. PMid:11240094.

Tafuri WL, Santos RL, Arantes RME, Gonçalves R, Melo MN, Michalik MSM, et al. An alternative immunohistochemical method for detecting Leishmania amastigotes in paraffin-embedded canine tissues. J Immunol Methods 2004; 292(1-2): 17-23. http://dx.doi.org/10.1016/j. jim.2004.05.009. PMid:15350508.

Toplu N, Aydogan A. An immunohistochemical study in cases with usual and unusual clinicopathological findings of canine visceral leishmaniosis. Parasitol Res 2011; 109(4): 1051-1057. http://dx.doi.org/10.1007/ s00436-011-2345-0. PMid:21479577.

Willis HH. A simple levitation method for detection of hookworm ova. Med J Aust 1921; 2(18): 375-376. 